\title{
'No way!' Discourse formulae of disagreement in Russian and English: a comparative study
}

\author{
Evgenia Koziuk \\ HSE University \\ Moscow, Russia \\ zhenya. yuryevna@gmail.com
}

\author{
Yulia Badryzlova \\ HSE University \\ Moscow, Russia \\ yuliya.badryzlova@gmail.com
}

\begin{abstract}
The study explores the discourse formulae (DFs) of disagreement in Russian and English belonging to the subclasses of refusal and prohibition. Starting with a subset of six Russian target DFs, we establish their English equivalents using corpus analysis. We also define the typical speech acts to which the DFs in both languages react, and design model contexts that exemplify these types of speech acts. We use the model contexts as stimuli in our Russian and English surveys where we look at the preferences of native speakers in choice of DFs across the speech acts. We use the data of the surveys to establish the pragmatic function of each DF, (i.e. refusal or prohibition, or both), and their potential in each subclass (strong, medium, or weak). For each DF, we also identify the types of speech acts to which they react most readily. We compare the results of our analysis to the lexicographic description of the target DFs as presented in the Russian-English Dictionary of Idioms.
\end{abstract}

Keywords: discourse formulae, disagreement, refusal, prohibition

DOI: $10.28995 / 2075-7182-2021-20-445-455$

\section{«Ещё чего!» Дискурсивные формулы несогласия в русском и английском языках: сравнительное исследование}

\author{
Козюк Е. Ю. \\ Национальный исследовательский \\ университет \\ «Высшая школа экономики» \\ Москва, Россия \\ zhenya.yuryevna@gmail.com
}

Бадрызлова Ю. Г.

Национальный исследовательский университет

«Высшая школа экономики»

Москва, Россия

yuliya.badryzlova@gmail.com

\begin{abstract}
Аннотация
В статье анализируются дискурсивные формулы (ДФ) несогласия в русском и английском языках, принадлежащие к подклассам отказа и запрета. Для шести русских ДФ мы устанавливаем их переводные эквиваленты в английском языке, используя анализ корпусных данных. Мы также выделяем типы речевых актов, которые являются наиболее характерными для рассматриваемых ДФ в обоих языках, и предлагаем набор модельных контекстов, иллюстрирующих каждый их этих типов. Полученные модельные контексты используются нами в качестве стимулов при опросе носителей русского и английского языка, в котором изучаются предпочтения в выборе той или иной ДФ в зависимости от типа речевого акта. На основе данных, собранных в ходе опроса, мы определяем прагматическую функцию каждой ДФ (т.е. принадлежность к подклассу отказа либо запрета, либо к обоим из них). Кроме того, полученные данные позволяют нам оценить потенциал ДФ в каждом из подклассов (высокий, средний или низкий). Мы также определяем, какие из типов речевых актов являются наиболее характерными для той или иной ДФ. Результаты исследования мы сопоставляем с лексикографическим описанием рассматриваемых ДФ в Русско-английском словаре идиоматических выражений.

Ключевые слова: дискурсивные формулы; несогласие; отказ; запрет
\end{abstract}




\section{Introduction}

The present work on discourse formulae is a spin-off of Russian Constructicon, a joint project by the National Research University (Moscow) and the Arctic University of Norway [1,2]. Russian Constructicon $^{1}$ is an online database of more than 2,000 Russian constructions accompanied by descriptions of their semantics, illustrative examples, and translations into English and Norwegian. According to Fillmore [3], constructions are primary units of language; they contain slots which are filled by variables, and carry syntactic, lexical, semantic, and pragmatic information. Constructions are non-compositional: the meaning of a construction is not equal to the aggregate of its components and their syntactic relations. However, when working on Russian Constructicon, its team observed constructions which are somewhat different in their nature: containing no empty slots, they constitute a completed utterance, and are used as separate sentences. We called them discourse formulae [4], e.g.:

(1) Votpusk tak xočetsja! - I ne govori.

'I so much wish I could go on vacation now! - You can say that again.'

Thus, the semantics of discourse formulae (DFs) is largely defined by their pragmatics; consequently, establishing cross-lingual equivalence of discourse formulae is a non-trivial task which requires application of corpus and survey methods.

The work on Russian DFs has branched off into a standalone project called Pragmaticon, currently in progress $^{2}$. The database of the state-of-the-art Pragmaticon contains approximately 800 DFs; they are divided into seven classes: agreement (ne vopros! 'no problem!'); confirmation (a kak že! 'of course!'); disagreement, consisting of three subclasses: refusal ( $n$ i za čto! 'no way!'), prohibition ( $\mathrm{ni} v$ koem slučae! 'out of the question!'), and negation (kak by ne tak! 'nothing of the kind!'); amazement (ničego sebe! 'holy cow!'); echo-questions (èto kak? 'how's that?'); devalorizaiton ( $\mathrm{kem}$ ne byvaet! 'things happen'), and indifference ( $k a k$ skažeš' 'if you say so') ${ }^{3}$. Beside semantic descriptions, Pragmaticon also features information on accompanying gestures and intonation, and translation equivalents in English, Slovenian, German, and Chinese.

Discourse formulae should be differentiated from other functionally similar phenomena described below.

Discourse words (e.g. Russian edva 'hardly', voobšče 'in fact', prjamo 'really') are extensively represented in dictionaries. Baranov et al. [5] differentiate several classes of discourse words; each class is characterized by a common semantic component, cf. the discourse words of incompleteness (e.g. edva, ele, čut' 'barely', s trudom 'with an effort' nemnogo 'a little', and počti 'almost').

Discourse markers (so, like, well, see, etc.) [6] function as constituent parts of utterances. They contribute to cohesion of the discourse, serving as linking devices, e.g.:

(2) Well, see, I guess what it is is the- um people get... t'be fifty eight, sixty, they move out of the houses, they move into an apartment. [7].

Unlike discourse markers, discourse formulae constitute a completed utterance and can be used autonomously.

Communicatives [8] are used in dialogues as reactions to interlocutor's utterances for stereotypical expression of evaluations, opinions, and emotions (e.g. Russian Net už 'No way', Kakoe tam! 'Nothing of the kind!', Obladet!! 'Oh boy!', Na zdorov'e! 'You are welcome!'). While communicatives can be one- or multi-word units, discourse formulae are always comprised of more than one word.

Speech formulae are defined by Baranov and Dobrovol'skij [9] as “...idiomatic expressions of various structural types (predominantly completed utterances) either possessing fixed illocutionary power or defining the illocutionary characteristics of an utterance ". The class of discourse formulae is narrower than that of speech formulae: the former are always used in response to a stimulus utterance (a certain speech act); therefore, DFs are identified in the context of a specific speech act to which they react.

Our study focuses on two subclasses of DFs of disagreement - refusal and prohibition. We examine a subset of Russian formulae of refusal and prohibition which are most representative of these subclasses. We conduct a corpus study in order to establish the English equivalents of the Russian DFs, as well as the types of speech acts that are most typical for the target DFs in both languages. We define

\footnotetext{
${ }^{1}$ The new website of Russian Constructicon is currently under development, available at https://constructicon.github.io/russian/. Should the location change, notification will be published on the project's website (https://site.uit.no/russian-constructi$\operatorname{con} /$ ).

${ }^{2}$ Pragmaticon will soon be available for access at https://pragmaticon.ruscorpora.ru/

${ }^{3}$ Since Pragmaticon is an ongoing project, the number and type of classes is subject to change.
} 
model contexts for each type of speech act and design Russian and English questionnaires in order to collect data on preferences of native speakers when choosing this or that DF for a particular speech act. We use the collected data to identify the pragmatic function of each Russian and English DF, i.e. to define whether they belong to the subclass of refusal or prohibition (or both). The survey data also allows us to assess the potential of each DF in its subclass (strong, medium, or weak), and the strength of association between each DF and specific types of speech acts. Finally, we compare our results with the descriptions of the target DFs as presented in the Russian-English Dictionary of Idioms [10].

\section{Present study}

DFs of refusal and prohibition serve to express directive negation; their main function is to preclude some future situation from happening. Specifically, the formulae of refusal are used when the speaker refuses to commit a certain action; as for the formulae of prohibition, it is the speaker who issues the prohibition on the interlocutor to commit a certain action. In both cases, the result is that a realistic future event becomes unreal due to the will of the speaker.

Russian Pragmaticon currently contains about 250 DFs of disagreement (in the three subclasses refusal, prohibition, and negation). For our study we have selected the following six DFs of refusal and prohibition: ešče čego, vot eščë, ni za čto, ni v koem slučae, i reči byt' ne možet, and tol'ko ne èto. The selection was made on the basis of frequency (i.e. DFs with the highest frequencies in corpora), lexical diversity (i.e. DFs expressed by diverse lexical means), and functional diversity (i.e. DFs reacting to a wide range of speech acts).

\subsection{Corpus analysis}

The English equivalents of the Russian target DFs were established using the parallel corpus Context Reverso ${ }^{4}$ and the online dictionary Multitran ${ }^{5}$. The candidate equivalents were verified by examining their occurrences in the Movie subcorpus of COCA (the Corpus of Contemporary American English) ${ }^{6}$ and consulting with native experts; additionally, the candidates were filtered by their frequency in the COCA. In the selection process we aimed at diversity, so as to avoid resembling formulae (cf. not for anything (in the world/on earth) and not for (all) the world); we also excluded DFs affiliated with the formal register and thus requiring specific contexts (e.g. by no means, on no account, nothing of the kind). The preliminary list of English equivalents and their distribution across the Russian formulae are shown in Table 1; at the subsequent stages of the present study this list will be put to test using corpus and survey data.

\begin{tabular}{|c|c|c|c|c|c|c|c|c|}
\hline & 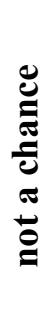 & 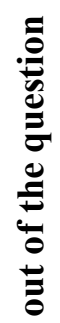 & $\begin{array}{l}\vec{\pi} \\
\stackrel{\pi}{\pi} \\
\stackrel{0}{0}\end{array}$ & 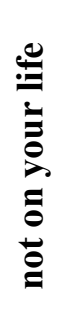 & 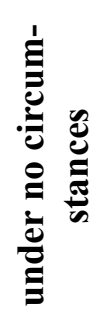 & 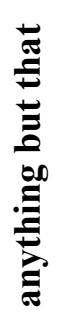 & $\begin{array}{l}\frac{a}{\bar{n}} \\
\bar{z} \\
\bar{\partial}\end{array}$ & 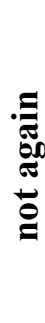 \\
\hline eščë čego & + & + & + & & & & + & \\
\hline vot eščë & + & & & & & & & \\
\hline ni za čto & + & & + & + & & & & \\
\hline ni v koem slučae & + & + & + & & + & & & \\
\hline i reči byt' ne možet & & + & + & & & & & \\
\hline tol'ko ne èto & & & & & & + & & + \\
\hline
\end{tabular}

Table 1: Preliminary distribution of English equivalents across Russian DFs.

\footnotetext{
${ }^{4} \mathrm{https}: / /$ context.reverso.net/translation/

${ }^{5} \mathrm{https}: / /$ www.multitran.com/

${ }^{6} \mathrm{https}: / /$ www.english-corpora.org/coca/
} 
In order to establish the classes of speech acts in which the Russian target formulae typically occur, we analyzed their occurrences in the Russian National Corpus (RNC) ${ }^{7}$ and defined the respective typical speech acts [see 11]. The English contexts were either translated from Russian, or selected from COCA. Nine classes of speech acts were identified (the gaps indicate the position of the DF):

(1) Offering help:

(Russian) Provodit' vas, tovarišč general? Mogu dvigat'sja bez postoronnej pomošči.

'Shall I accompany you, comrade General? .I am capable of walking by myself.' (English) Let me help you I'm not a little girl. I can do it myself.

(2) Command:

(Russian) Poguljaj s sobakoj. Počemu vsegda ja?

'Go walk the dog. Why is it always me?'

(English) Help your sister do her homework. I have my own homework to do.

(3) Advice:

(Russian) Uxodi v otstavku, uezžaj kuda-nibud'. Ty sam ponimaeš', čto èto bylo by begstvo.

'Resign from office, leave the town!'You know perfectly well this would mean retreat.'

(English) You should visit the Tate Modern when you're in London.I hate modern art.

(4) Asking for advice:

(Russian) Možet, mne ne stoit publikovat' knigu? 'The book may not be worth publishing, may it? (English) Should we invite Steve to the party? -

(5) Suggesting joint activity: (Russian) Davaj letom za granicu poedem? 'Let's go abroad this summer?' (English) Let's fly business class. Vse uže rě̌eno. It is a settled matter now.' He was rude to me last week.

(6) Request:

(Russian) Požalujsta, otdaj mne svoi starye krossovki. 'Will you let me have your old sneakers? Tol'ko na daču! (English) Can you recite your poetry? . I need them myself!' to anyone.

(7) Asking for permission:

(Russian) Možno ja druga provožu? On ne malen'kij, sam dorogu znaet. 'May I see my friend off? (English) Can I see my friend off? He is not a little boy, he knows the way.' . He is not a little boy. He knows the way.

(8) Commissive: (Russian) Vot čto značit zimoj bez šapki xodit'. Ja sejčas že vzyvaju vrača! . Ja prosto vyp'ju čaja s limonom, $i$ vse projdet.

'This is what you get for walking around bareheaded in winter! I am calling the doctor immediately! I will just drink tea with lemon, and it all will go.'

(English) Thanks for the meal. I'll pay. . I invited you!

(9) Question on future intension:

(Russian) Ty dumaeš' stixi pisat'? 'Are you thinking of writing poetry? (English) Are you planning to become a lawyer? Ja ubedilsja, čto u menja ničego ne vyxodit. lations. I have tried and seen I am none of a poet.' I'm studying international re-

The nine types of target speech acts are divided between the two subclasses (refusal and prohibition) as follows:

- Refusal: command, request, suggesting joint activity, advice, and question on future intension.

- Prohibition: asking for permission, asking for advice, offering help, and commissive.

\footnotetext{
${ }^{7}$ https://ruscorpora.ru/new/
} 
We expect that some of the target formulae will gravitate towards one of the subclasses, while others may be used in both of them. Noticeably, as seen in Table 1, the English no way and not a chance correspond to the majority of the Russian DFs, and therefore are expected to be dominant, i.e. to fit most of the stimulus contexts (1-9).

\subsection{The survey}

The contexts of the prototypical speech acts (1-9 above) were compiled into two questionnaires (Russian and English, respectively), which were offered to respondents ${ }^{8}$. The respondents could choose any number of DFs to fill in the gaps, without ranking them. The questionnaires were administered via Google Forms. The Russian questionnaire was filled by 34 native speakers of Russian, age 18-55, women $70.5 \%$. The respondents of the English survey were 40 native speakers of English, age 20-66, women $56.1 \%$. In regard to the variety of English spoken, $61 \%$ identified as speakers of American, $17.1 \%$ of British, $19.5 \%$ of Canadian, and $2.4 \%$ of Australian English. All respondents in both samples confirmed that they are not professional linguists; every respondent gave their informed consent to participate in the experiment.

\section{Results}

The results of the survey are visualized in Figures 1-3. The heatmap in Figure 1 shows how the DFs are distributed across the speech acts, and how the speech acts align with the two subclasses (refusal and prohibition); thus, Figure 1 highlights the dominant speech acts for each DF. Figure 2 contains averaged numbers across the speech acts in each of the two subclasses; it allows us to judge to which of the subclasses (refusal or prohibition) each DF belongs. Figure 3 demonstrates the results of correspondence analysis $^{9}[12-14]$ between DFs and speech acts; it allows up to make judgements about the centrality of each formula in the class of disagreement: the nearer to the center, the more dominant the DF is; the farther off the center, the more peripheral it is. (For convenience of presentation, we do not show the speech acts in this plot.)

\subsection{Analysis of Russian DFs}

The formulae eščë čego and vot ešče belong to both subclasses - prohibition and refusal, and react to the majority of speech acts. Their dominant speech acts are: command, request, suggesting joint activity, asking for permission, and offering help. Besides, vot ěšce can be used in the speech act of devalorizaiton (which is not discussed in this paper), i.e. for negative evaluation of situation.

The DFs ni v koem slučae and $i$ reči byt' ne možet belong to the subclass of prohibition. The dominant speech acts of ni v koem slučae are advice and commissive; slightly less dominant is the act of asking for help. The dominant speech acts of $i$ reči byt' ne možet are advice and asking for advice, while asking for permission is also dominant, but to a lesser degree. When reacting to advice (i.e. expressing refusal), the refusal expressed by these two DFs is somewhat different from what happens when the speaker uses the two dominant formulae of refusal - ešče čego and vot ě́čë. In the latter case, the speaker expresses reluctance to follow the advice, whereas in the former the speaker informs the interlocutor about the impossibility of following the advice, cf. (10) and (11):

(10) Da ty by na nego načal'stvu požalovalas!! - Vot ešče / ešče čego, iz-za takix pustjakov načal'stvo bespokoit'.

'You should complain to the authorities about him! - No way! Bothering the authorities about such trifles!

(11) Da ty by na nego načal'stvu požalovalas!! -Ni v koem slučae / i reči byt' ne možet, iz-za takix pustjakov načal'stvo bespokoit'.

'You should complain to the authorities about him! - That's out of the question! Bothering the authorities about such trifles!

The DF ni za čto belongs to the subclass of refusal. Its dominant speech acts are suggesting joint activity, request, and advice. However, it can also act as prohibition in reaction to offer of help and commissive.

\footnotetext{
${ }^{8}$ The full version of the questionnaires is available at https://docs.google.com/document/d/1_ZQIOuyfjIvexgzRM-

n_0fcLg5V0g1yDRk-z3vUHIjA/edit?usp=sharing

${ }^{9}$ Prince, the Python factor analysis library: https://pypi.org/project/prince/
} 

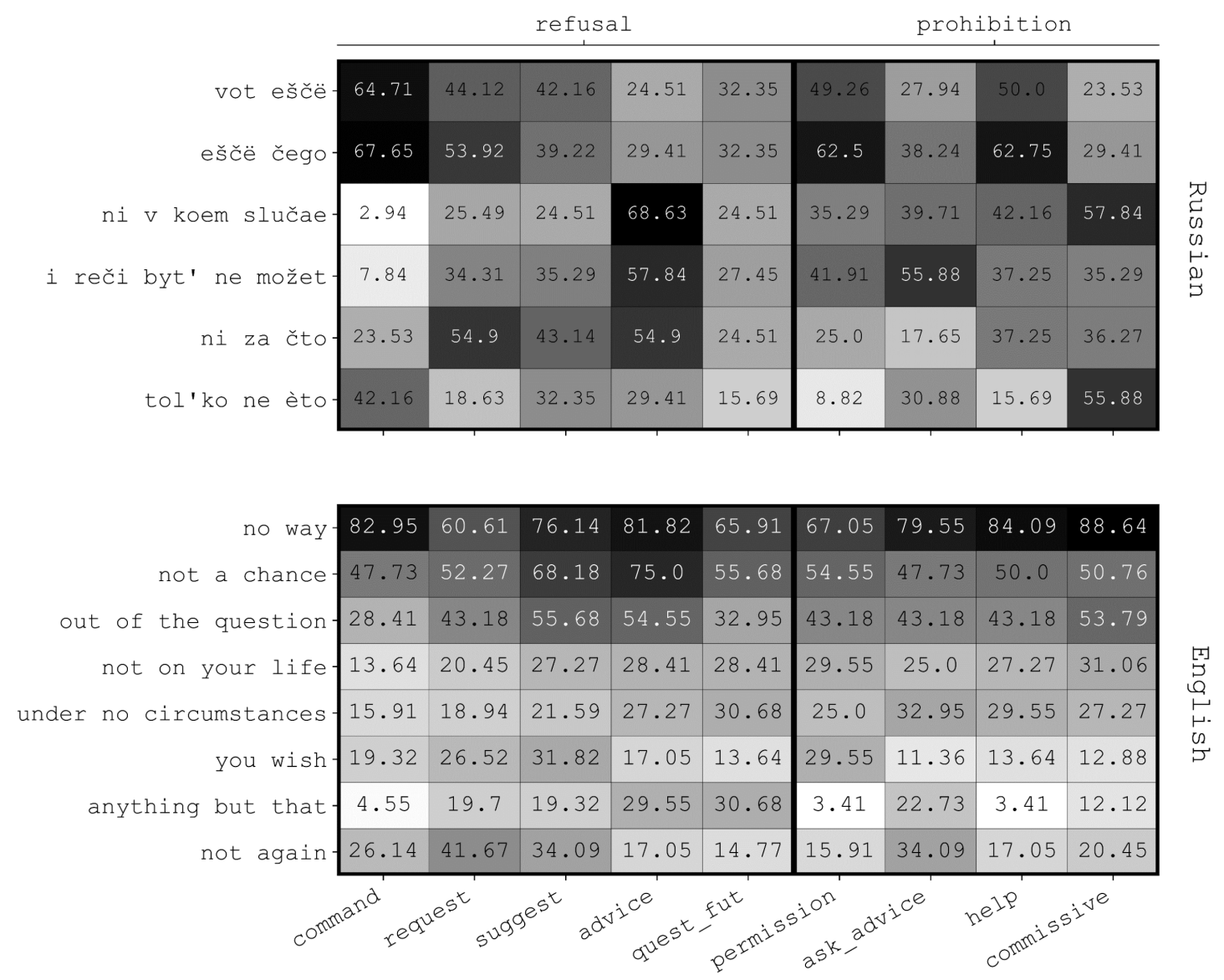

Figure 1: Distribution of DFs across speech acts, \% (suggest = suggesting joint activity, quest_fut $=$ question on future intention, permission $=$ asking for permission, ask_advice $=$ asking for advice, help = offering help).

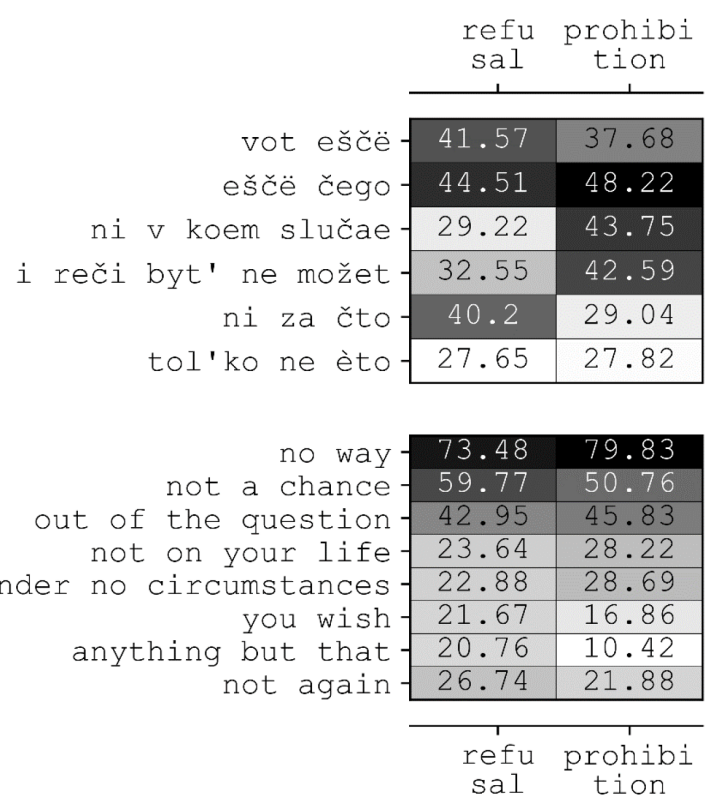

Figure 2: Distribution of DFs between the subclasses of refusal and prohibition, $\%$. 

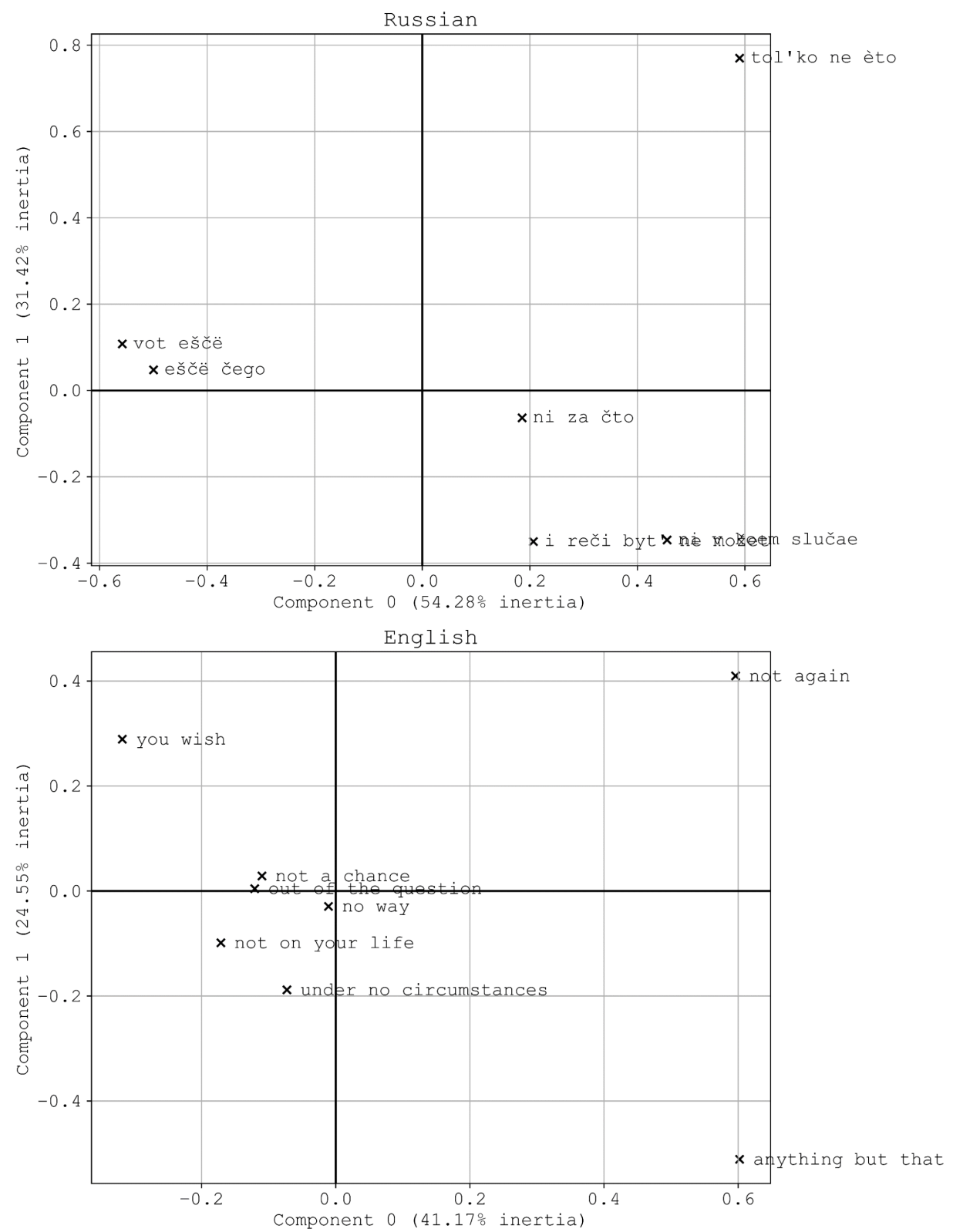

Figure 3: Correspondence analysis between DFs and speech acts.

Yet, as compared to ni v koem slučae and $i$ reči byt' ne možet, ni za čto is chosen less frequently for expression of prohibition.

The formula tol'ko ne èto is peripheral in the class of disagreement.

\subsection{Analysis of English DFs}

No way and not a chance are the dominant DFs in both classes, refusal and prohibition. Still, no way is relatively more dominant than its counterpart: no way is strongly preferred in all the contexts of refusal and prohibition, whereas not a chance is comparatively weakly preferred in the contexts of command and asking for advice. Besides, the refusal and prohibition conveyed by no way are more emotionally charged.

Out of the question also belongs to both of the subclasses, refusal and prohibition, although is a less dominant formula than no way and not a chance. Its most dominant speech acts are advice, commissive, and suggesting joint activity.

Not on your life and under no circumstances show moderate reaction to the speech acts of prohibition, and somewhat weaker reaction to the speech acts of refusal - in particular, to command and request. The 
speech act of refusal to which they react most readily is in response to question on future intensions, e.g.:

(12) Would you share a room? - Not on your life / under no circumstances. I really don't like her personality.

You wish contains a negative evaluative component; it can express both refusal (in the speech acts of command, request, and suggesting joint activity) and prohibition (when asking for permission). Yet, its major function is that of refusal.

Anything but that and not again are peripheral DFs of disagreement. Additional corpus analysis of these formulae showed that not again is preferred in situations when the interlocutor repeatedly addresses the speaker with a suggestion or resumes previous conversation. If the participants of the dialogue are speaking about a new topic or subject, anything but that is preferred.

\subsection{Exploring pragmatic potential of the DFs}

The observations on the Russian and English DFs presented in Sections 3.1 and 3.2 can be summarized as shown in Table 2. The most distinct group of DFs is formed by the Russian vot ěšce and ešče čego and the English no way and not a chance: they all are dominant, manifesting strong association with both refusal and prohibition. (Having said that, it should be noted that the dominance of the Russian DFs is much less pronounced than that of their English counterparts.)

The next group is presented by DFs with strong-medium association with the subclass of prohibition, and medium-weak association with the subclass of refusal: the Russian ni v koem slučae and $i$ reč $i$ byt ne možet, and the English out of the question, not on your life, and under no circumstances.

The pair of DFs ni za čto (Russian) and you wish (English) comprises the group distinguished by weak association with the subclass of prohibition and strong-medium association with the subclass of refusal.

The Russian tol'ko ne èto, along with the English anything but that and not again, are peripheral DFs in the class of disagreement.

\begin{tabular}{|c|l|c|c|c|}
\hline Language & \multicolumn{1}{|c|}{ DF } & Refusal & Prohibition & Periphery \\
\hline Rus & vot eščë & strong & strong & \\
\hline Rus & eščě čego & strong & strong & \\
\hline Eng & no way & strong & strong & \\
\hline Eng & not a chance & strong & strong & \\
\hline Rus & ni v koem slučae & weak & strong & \\
\hline Rus & i reči byt' ne možet & weak & medium & \\
\hline Eng & out of the question & medium & medium & \\
\hline Eng & not on your life & weak & medium & \\
\hline Eng & under no circumstances & weak & medium & \\
\hline Rus & ni za čto & strong & weak & \\
\hline Eng & you wish & medium & weak & \\
\hline Rus & tol'ko ne èto & & & strong \\
\hline Eng & anything but that & & & strong \\
\hline Eng & not again & & & strong \\
\hline
\end{tabular}

Table 2: Profiles of Russian and English DFs.

\subsection{Russian-English equivalence finalized}

The translation equivalence between the Russian and the English DFs which has been confirmed in the course of our study can be summed up as follows (Table 3):

Vot ěšëe and ěšce čego, when used in the function of refusal, carry a connotation of negative evaluation; the same applies to their common English equivalent not a chance (when expressing refusal) and to the English equivalent of ešče čego, the DF you wish. To express prohibition, both of these Russian DFs can be translated by the dominant English DF no way. 


\begin{tabular}{|c|c|c|c|c|c|c|c|c|}
\hline & 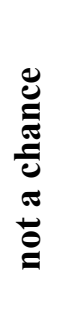 & 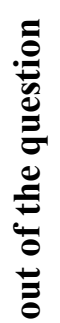 & 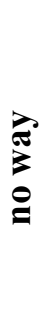 & 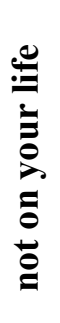 & 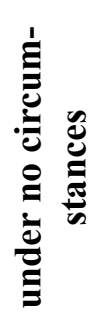 & 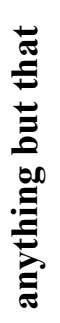 & $\begin{array}{l}\frac{5}{0} \\
\overline{0} \\
\overline{0} \\
\lambda\end{array}$ & 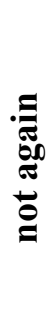 \\
\hline eščë čego & + & + & + & & & & + & \\
\hline vot eščë & + & & + & & & & & \\
\hline ni za čto & + & & + & + & & & & \\
\hline ni v koem slučae & + & + & + & & + & & & \\
\hline i reči byt' ne možet & + & + & + & & & & & \\
\hline tol'ko ne èto & & & & & & + & & + \\
\hline
\end{tabular}

Table 3: Revised distribution of English equivalents across Russian DFs. Cells with darker grey background correspond to confirmed equivalents; slate-grey cells correspond to confirmed equivalents with limited functionality.

In the case of expressing refusal, $n i$ za čto is an emotionally loaded DF. Its closest English equivalent is the dominant formula no way (particularly in commands and suggestions about joint activity, where it expresses categorical refusal). Ni za čto can also be translated by means of the other dominant English $\mathrm{DF}$, not a chance - mainly in questions about the speaker's intentions and in suggestions about joint activity. Equally well, ni za čto can be rendered by not on your life - primarily in response to commands and suggestions about joint activity, where both DFs, as a rule, express refusal to carry out the action on the speaker's own will rather than due to impossibility.

Ni v koem slučae can be translated as no way both in the function of refusal and prohibition; in certain cases it can also be translated by out of the question (for refusal to follow advice and for commissive prohibition) and by under no circumstances (in response to request for advice and as commissive).

The most preferable English equivalent of $i$ reči byt' ne možet - both in the function of refusal and prohibition - appears to be no way, yet the Russian DF can also be translated by out of the question.

The peripheral Russian DF of refusal tol'ko ne èto is typically used for negative evaluation; its English equivalents are anything but that (for negative assessment and refusal) and not again (when the speaker is reluctant to repeatedly commit an action or to be told once again something they have already heard).

\subsection{Comparison with lexicographic description}

In order to assess the reliability of our results we chose to compare them to the descriptions of the target DFs presented in the Russian-English Dictionary of Idioms (REDI, hereafter) [10]. This dictionary was chosen as one of the most comprehensive and academically acclaimed Russian-English lexicographic sources; it is based on parallel translations of Russian fiction literature, thus providing common ground for the comparison. Table 4 shows how the findings of the present study about the equivalence between the subsets of the six Russian and eight English DFs align with their description in REDI: column A contains the equivalents stated in this study but missing in REDI; column B presents the equivalents that are indicated in REDI but have not been confirmed in this study; and column $\mathrm{C}$ lists the equivalents where both sources agree.

The DF vot ěšce is described in REDI as belonging only to the subclass of refusal (whereas our results suggest that it belongs to both subclasses); besides, the other English equivalents of vot ešče in the dictionary are characterized by strong expressivity and emotionality, cf.: what (on earth) are you talking about!, you've got to be kidding!, you must be out of your mind. As for the equivalent suggested by our research - not a chance - it is not present in REDI. We think that, as expressive a DF as vot ešce is, it can also appear in contexts without distinct emotional expression; in such cases not a chance would be the most apt translational equivalent. 


\begin{tabular}{|c|c|c|c|}
\hline DF & $\begin{array}{c}\text { A. } \\
\text { This study REDI }\end{array}$ & $\begin{array}{c}\text { B. } \\
\text { This study REDI }\end{array}$ & $\begin{array}{c}\text { C. } \\
\text { This study REDI }\end{array}$ \\
\hline vot eščë & not a chance & $\varnothing$ & $\varnothing$ \\
\hline eščë čego & $\begin{array}{c}\text { not a chance } \\
\text { you wish } \\
\text { out of the question }\end{array}$ & not on your life & no way \\
\hline ni za čto & not a chance & $\varnothing$ & $\begin{array}{l}\text { not on your life } \\
\text { no way }\end{array}$ \\
\hline tol'ko ne èto & $\begin{array}{c}\text { anything but that } \\
\text { not again }\end{array}$ & [unavailable] & $\varnothing$ \\
\hline ni v koem slučae & $\begin{array}{c}\text { not a chance } \\
\text { out of the question }\end{array}$ & $\varnothing$ & $\begin{array}{c}\text { no way } \\
\text { under no circumstances }\end{array}$ \\
\hline i reči byt' ne možet & no way & $\varnothing$ & out of the question \\
\hline
\end{tabular}

Table 4: Russian-English equivalents, comparison between this study and REDI ( $\varnothing$ denotes an empty set, i.e. absence of English equivalents in either of the sources or in their intersection, respectively).

The DF ešče čego is referred by REDI to the subclass of refusal, with the most characteristic speech acts being suggestion about joint activity and request; this partially agrees with our data, where this DF is dominant in both subclasses, refusal (most prominently, in commands) and prohibition (particularly, in the speech acts of asking for permission and offering help). Among the English equivalents of ešče čego REDI lists two of our DFs - no way and not on your life. While we admit that no way, being a dominant $\mathrm{DF}$, may also be capable of corresponding to ešče čego in translation, it is not the case with not on your life. Unlike its Russian counterpart, ešče čego, the English DF not on your life can be used in speech acts of prohibition only to a limited extent (see Section 3.3); moreover, when reacting to commands, not on your life should be translated with the Russian DF ni za čto. REDI does not list not a chance and you wish as English equivalents of the Russian ešče čego, whereas our study shows that there is equivalency between them, as all of these DFs contain a negative evaluative component.

The Russian DF ni za čto is defined in REDI as 'on no condition, under no circumstances', featuring two English equivalents from our list of DFs - not on your life and no way; however, REDI makes no mention of not a chance, which corresponds to ni za čto in the contexts of refusal to engage in joint activity.

The Russian DF tol'ko ne èto is not represented in REDI whatsoever; the dictionary contains similar DFs tol'ko ètogo ne xvatalo and ěše čego ne xvatalo and suggests the following DFs as their English equivalents: that's the limit, that's the last straw, etc. - that is, DFs with a strong component of indignation in their semantics. REDI also points out that these English DFs are used to express categorical and impolite refusal to accept the interlocutor's suggestion - which is dramatically different from the characteristics of the Russian DF tol'ko ne èto.

The Russian DF ni v koem slučae is primarily described by REDI as a construction occurring in nondialogue utterances, cf::

Ja ni v koem ne dopuskaju mysli, čto...

'By no means do I admit the idea that...'

According to REDI, the English equivalents of ni v koem slučae are the DFs not for one moment, there's no way, and others; yet the dictionary also lists two of the English DFs suggested by our study: no way and under no circumstances. REDI does not mention the other two of our suggested equivalents - out of the question and not a chance, which, similarly to ni v koem slučae, serve to express prohibition.

The Russian DF i reči byt' ne možet is placed by REDI in the class of categorical refusal and rejection, whereas, according to our data, this DF can also be associated with the subclass of prohibition. Similarly to our study, REDI lists the DF out of the question as an English equivalent of DF $i$ reči byt' ne možet, although treating it as a non-dialogue utterance of the type $X$ is out of the question; besides, REDI does 
not mention no way, which, according to our analysis, corresponds to this Russian formula in speech acts of categorical refusal.

\section{Conclusions}

Being pragmatic units, discourse formulae pose a difficult problem in translation. Defining cross-lingual equivalents of DFs requires multi-faceted analysis involving dictionaries as well as data from corpora and surveys. Using corpus analysis, we identified the English equivalents of the Russian DFs of disagreement. We also conducted a survey in order to establish to which of the two subclasses of disagreement - refusal or prohibition - the target Russian and English DFs belong. The results indicate that the English formulae have a broader coverage - most of them belong to both of the subclasses, whereas the Russian formulae tend to be more specialized in their affiliation with either subclass; yet, they can occasionally react to speech acts from the opposite subclass. In both sets of DFs, we identify peripheral formulae with marginal frequency and coverage. Besides, we demonstrate that the choice of DFs can be affected by finer pragmatic nuances of the context. The results of the study will be incorporated into Pragmaticon, the database of Russian discourse formulae. The approach suggested in this paper may contribute to advancement of the practices of cross-lingual lexicographic description of DFs.

\section{Acknowledgements}

This work is supported by the Ministry of Science and Higher Education of the Russian Federation (07515-2020-793).

\section{References}

[1] Janda L.A. et al. A Constructicon for Russian: Filling in the Gaps. // Constructicography: Constructicon development across languages. 2018.

[2] Endersen A. et al. The Russian Constructicon: a new linguistic resource, its design and key characteristics // Computational Linguistics and Intellectual Technologies. 2020.

[3] Fillmore C.J., Kay P., O'Connor M.C. Regularity and idiomaticity in grammatical constructions: The case of let alone // Language. 1988. P. 501-538.

[4] Puzhaeva S. et al. Automated extraction of discourse formulas from Russian texts [Avtomatičeskoe izvlečenie diskursivnyx formul iz tekstov na russkom jazyke] // Bulletin of Novosibirsk State University. Series: Linguistics and Intercultural Communications. 2018. Vol. 16, № 2.

[5] Baranov A., Plungian V., Rakhilina E. A guide to Russian discourse words [Putevoditel' po diskursivnym slovam russkogo jazyka]. Moscow: Pomovsky \& Partners, 1993.

[6] Schiffrin D. Discourse Markers. Cambridge: Cambridge University Press, 1987.

[7] Schiffrin D. Discourse markers: Semantic resource for the construction of conversation: Unpublished doctoral dissertation. University of Pennsylvania, 1982.

[8] Sharonov I. Discourse words and communicatives [Diskursivnye slova i kommunikativy] // Computational Linguistics and Intellectual Technologies. 2016. № 15. P. 22.

[9] Explanatory dictionary of Russian phraseology [Frazeologičeskij ob"jasnitel'nyj slovar' russkogo jazyka] / ed. Baranov A., Dobrovol'skij D. Litres, 2017.

[10] Lubensky S. Russian-English dictionary of idioms. Yale University Press, 2014.

[11] Rakhilina E., Bychkova P., Zhukova S. Rečevye akty kak lingvističeskaja kategorija. Diskursivnye formuly [Speech acts as a linguistic category. Discourse formulae]. // Voprosy jazykoznanija [Topics in the study of language]. 2021. Vol. 2.

[12] Hirschfeld H.O. A connection between correlation and contingency // Mathematical Proceedings of the Cambridge Philosophical Society. Cambridge University Press, 1935. Vol. 31, № 4. P. 520-524.

[13] Fisher R.A. The precision of discriminant functions // Annals of Eugenics. Wiley Online Library, 1940. Vol. 10, № 1. P. 422-429.

[14] Greenacre M. Correspondence analysis in practice. Chapman and Hall/CRC, 2007. 